J. Perinat. Med. 16 (1988) 357

\section{Computerized analysis of behavioural states in asymmetrical growth retarded fetuses}

\author{
Domenico Arduini', Giuseppe Rizzo', Carlo Romanini' ${ }^{2}$, Salvatore Mancuso' \\ ${ }^{1}$ Dept. of Obstetrics and Gynecology Universita' Cattolica S. Cuore Rome, Italy \\ ${ }^{2}$ Dept. of Obstetrics and Gynecology Universita' di Ancona, Italy
}

\section{Introduction}

The contribution of fetal asymmetrical intrauterine growth retardation (IUGR) to perinatal mortality and morbidity $[8,16]$ is well-known and the management of IUGR fetuses is correctly considered as one of the clinical issues in perinatal medicine.

Asymmetrical IUGR fetuses are characterized by a redistribution of cardiac output with diversion of a higher blood flow rate to vital organs such as brain and heart and this results in a relative brain sparing with respect to body-weight as demonstrated in experimental animal models [12] and more recently in humans [4]. There is no documentation, however, whether this condition of preferential cerebral perfusion allows development of the Central Nervous System (CNS) analogous to that of healthy fetuses.

Behavioural states are a direct expression of CNS function [7, 13] and their assessment has been recently suggested as a new approach to the study of the functional condition of the fetus [11]. In order to investigate possible quantitative variations in the behaviour of IUGR fetuses with respect to healthy fetuses we performed a computerized analysis of several fetal behavioural variables including heart rate, eye movements, gross body movements and breathing movements.

\section{Materials and methods}

After informed consent had been obtained, the assessment of fetal behavioural state was performed on 15 multiparous pregnant women doc-

\section{Curriculum vitae}

DOMENICO ARDUINI was born in 1950 and received his M.D. in 1976. He has been specialist in Obstetrics and Gynecology since 1980. At present he is a researcher at the Department of Obstetrics and Gynecology of Universita' Cattolica Sacro Cuore Roma. His fields of interest include cardiotocography, ultrasound, doppler analysis of fetal blood flow, use of computer in perinatal medicine.

umented to have an asymmetrical IUGR fetus whose gestational age lay between 36 and 38 weeks. IUGR was defined by the presence of ultrasonographic signs (BDP and abdominal circumference below the 10th percentile according to the nomograms of CAMPBELL \& THOMS [6]) and postnatal confirmation by a birthweight below the 10th centile according to our population standards [9] after correction for mother's height, weight and parity and the sex of the newborn. Increase in the head to abdomen circumference ratio [6] was the basis for classification as asymetrical growth retardation. As a control group we selected 15 healthy multiparous pregnant women at the same gestational age. All the infants of this latter group had a good outcome and a birthweight above the 25th centile. All were singleton pregnancies and had been accurately dated with early second trimester ultrasonographic examinations. 
Recordings were performed, two hours after a $1500 \mathrm{Kcal}$ standardized lunch, in a quiet room with the women lying in a comfortable semi-recumbent position using a previously reported technique [3].

Fetal heart rate (FHR), fetal gross body movements (FM), fetal eye movements (FEM) and fetal breathing movements (FBM) were simultaneously recorded for two consecutive hours. FHR was obtained by means of a Hewlett Packard 8030 A cardiotocograph with an esternal ultrasound transducer. FEM, FM and FBM were determined by two observers using two real-time ultrasound machines (Ansaldo AUC 940 and Ansaldo Esacord 80) with the transducers postioned in order to obtain a parasagittal section through the fetal face and a transverse section at the level of the upper part of fetal abdomen respectively. The two observers recorded individual movements into our computerized system using two remote switching devices and pushing codified keyboards for signalling the onset and the end of each movement. Similarly the observers entered the "failure" periods during which a reliable view of the fetal lens or trunk was not obtained. Analogue to digital conversion of the movements was performed at a sampling interval of 50 milliseconds. Data were then stored and processed by a Digital FDP 11 computer [15]. At the end of the recordings an offline analysis of the FHR was performed using a three-minute moving window. As previously reported FHR was classified into four patterns (A to D) according to NIJHUIS et al. [10]:

- Fetal heart rate pattern (FHRP) A: Heart rate stable with a variability of less than $10 \mathrm{bpm}$. Isolated accelerations are strictly related to movements.

- FHRP B: Heart rate with a variability greater than $10 \mathrm{bpm}$ and numerous accelerations present. - FHRP C: Heart rate stable with a variability of more than $10 \mathrm{bpm}$ and absence of accelerations.

- FHRP D: Heart rate unstable with marked and long-lasting accelerations.

The classification of each cardiocographic epoch was entered into the computer and the movements were automatically synchronized with FHR and grouped for each FHRP. This system enabled us to compute for each movement incidence, mean duration, lag time (mean interval between the onset of two consecutive movements) as well as the percentage time spent moving during the four different FHR patterns for each movement. More- over FEM were divided into three further classes on the basis of their frequency in 1-minute epochs. As previously reported by us [1] FEM were considered rapid (REM) with more than six movements of the lens every minute, intermittent (IEM) when their frequency ranged between one and six movements and absent when no such movements were seen.

Finally the coincident relationships between FHRP, FM and FEM were automatically computed. The stable ( $>3 \mathrm{~min}$ ) agreement and the simultaneous changes of all these three parameters were necessary for classification into one of four different behavioural states as outlined below:

1F (quiet sleep): FHRP A, absence of FM and FEM

2F (active sleep): FHRP B, presence of FM and FEM

3F (quiet awake): FHRP C, presence of FEM and absence of FM

4F (active awake): FHRP D, presence of FM and FEM.

In absence of these conditions epochs were classified as periods of "no coincidence". Data are presented as mean values \pm 1 standard deviation. Statistical analysis was performed by means of paired $\mathrm{t}$ test and chi-square test.

\section{Results}

The incidence of FHRP is reported in figure 1. No statistical differences (chi square n.s.) are found between the two groups. In both groups FHRP are mainly represented by FHRP A and FHRP B. The incidence of FHRP C and D is too low to obtain reliable analysis of FBM, FM and FEM distributions during these FHRP.

Table I provides the quantitative analysis of fetal movements during FHRP A and B. Concerning FM the differences between normal and IUGR fetuses are particularly evident during FHRP B where IUGR fetuses show a reduction in the number, duration and percentage of time spent moving. Moreover during FHRP A, IUGR fetuses exhibit a significant increase only in the number of FM with respect to the control group.

IUGR fetuses show an increase of number and percent of time spent moving of FEM during FHRP A, whilst an increase in duration and lagtime associated with a decrease in number is evident in FHRP B. The relatively high frequency of FBM restricted the analysis to the clusters of 


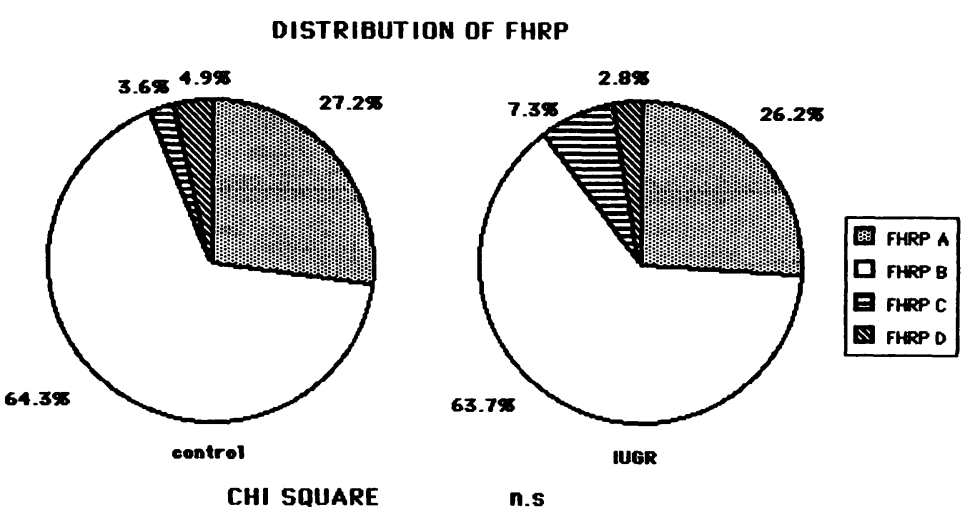

Figure 1. Distribution of fetal heart rate patterns (FHRP) in healthy (controls) and IUGR fetuses.

Table I. Comparison of quantitative analysis of fetal movements in healthy (control) and IUGR fetuses during FHRP A and B.

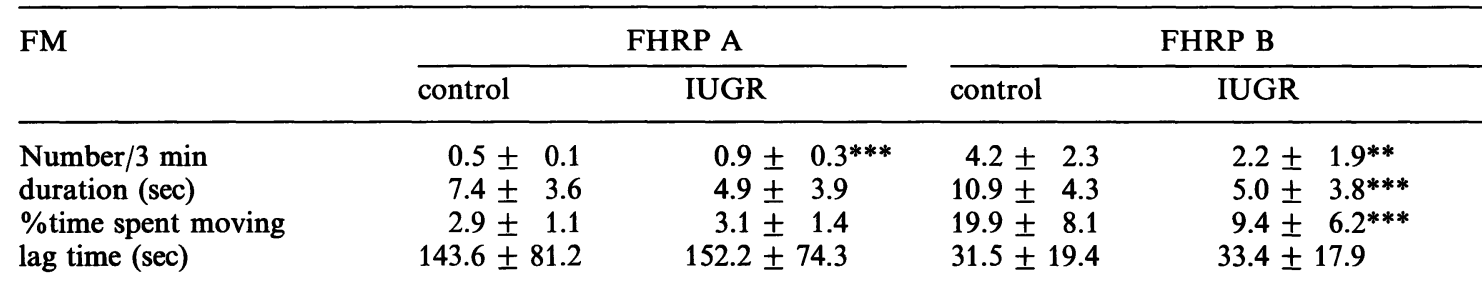

FEM

$\begin{array}{lrcrr}\text { Number/3 min } & 1.9 \pm 0.9 & 6.2 \pm 3.2^{* * *} & 24.3 \pm 9.2 & 12.7 \pm 5.6^{* * *} \\ \text { duration }(\mathrm{sec}) & 1.5 \pm 0.4 & 1.6 \pm 0.7 & 0.7 \pm 0.3 & 1.6 \pm 0.4^{* * *} \\ \text { \%time spent moving } & 1.6 \pm 0.3 & 4.9 \pm 1.8^{* * *} & 9.5 \pm 3.7 & 8.3 \pm 4.1 \\ \text { lag time (sec) } & 78.5 \pm 28.5 & 80.6 \pm 30.4 & 11.4 \pm 7.8 & 26.3 \pm 9.2^{* * *}\end{array}$

FBM (cluster)

duration (sec)

$\%$ time spent moving

lag time (sec)

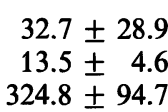

$29.5 \pm 32.6$
$15.4 \pm 5.2$
$307.8 \pm 89.4$
$65.9 \pm 34.8$

$42.3 \pm 21.4$

$81.7 \pm 34.2$

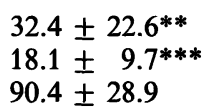

$32.4 \pm 22.6^{* * *}$
$18.1 \pm 9.7^{* * *}$

$90.4 \pm 28.9$ movement. Their duration, percent of time spent moving and lag-time are calculated. Evidence of significant differences between the two groups is seen only during FHRP B, when IUGR fetuses show a reduction in duration and percent of time spent moving in FBM clusters.

Figure 2 shows the distribution of FEM according to their 1-minute frequency. In healthy fetuses FEM are mainly represented by REM during
FHRP A and absence during FHRP B. Conversely an increase of IEM during both FHRP A and B is evident in IUGR fetuses. The differences between these frequences reach statistical significance (chi square $p<0.001$ ). The incidence of fetal behavioural states is plotted in figure 3 . IUGR fetuses show a decreased incidence of state $1 \mathrm{~F}$ and an increase of periods of no coincidence when compared to the control group (chi square $\mathrm{p}<0.001)$. 


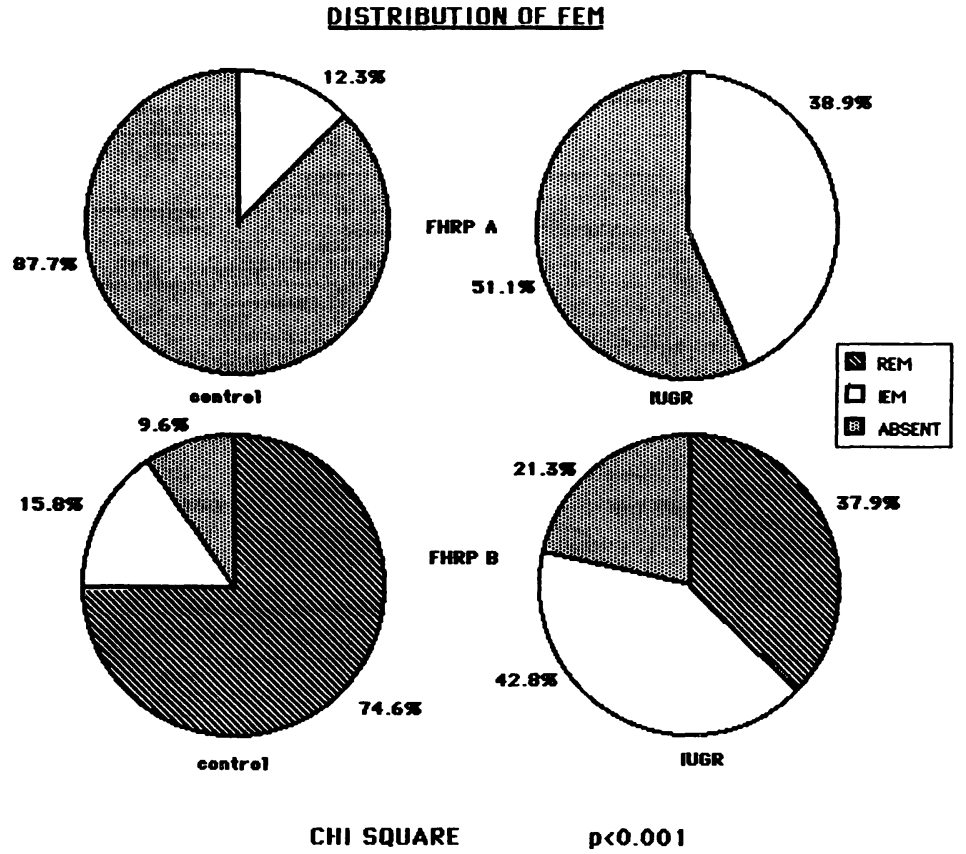

Figure 2. Distribution of fetal eye movements (FEM) on the basis of their 1-minute frequency during FHRP A and $\mathrm{B}$.

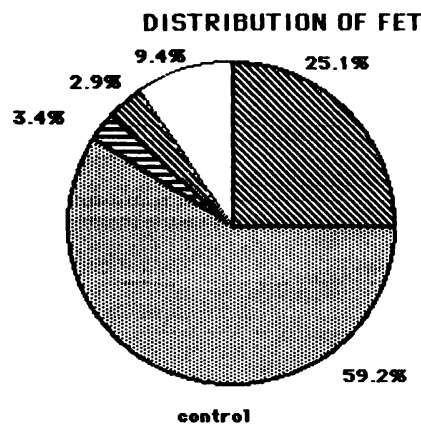

CHI SQUARE

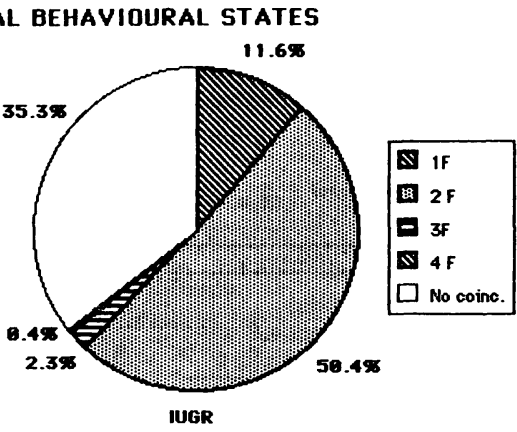

$P<0.001$

Figure 3. Distribution of behavioural states in control group and IUGR fetuses.

\section{Discussion}

The present results confirm the presence of abnormal qualitative findings in behavioural states of IUGR fetuses as previously reported by us [14] and others [18]. It is noteworthy that the distribution of FHRP is similar in healthy and IUGR fetuses suggesting that the isolated analysis of fetal heart rate does not assist an making early diagnosis of fetal distress in cases of growth retardation.
The high incidence of IEM-type of FEM in IUGR fetuses is similar to the condition present in healthy fetuses at an earlier gestational age [2] suggesting that there is a delay in the control system of eye movements in growth retardation. Similarly the low incidence of quiet sleep $(1 \mathrm{~F})$ and the increase of periods of no coincidence exhibited by IUGR, show that these fetuses have not attained the same level of organization as healthy fetuses. 
The computerized analysis performed in this study provides further quantitative data on fetal movements and on their relationship to behavioural states. IUGR fetuses show a similar duration on all the movements analyzed during both FHRP A and $B$, whilst in healthy fetuses a significative reduction in the duration of movements is evident during FHRP A. Furthermore the differences in number and percent of time spent moving between FHRP A and FHRP B of FM, FEM and FBM that characterize healthy fetuses, are not so evident in IUGR fetuses. The latter group shows a more homogeneous distribution of movements in both FHRP A and B. A slight quantitative reduction of FM and FBM in IUGR fetuses has also been reported by other investigators $[5,17]$ but these results showed a marked overlap with those found in healthy fetuses. However, these studies did not consider the influence of behavioural states. Our

\section{Summary}

The fetal behaviour of 15 asymmetrical intrauterine growth retarded (IUGR) fetuses was compared to that of a control group of healthy fetuses. Fetuses underwent simultaneous cardiotocographic and ultrasonographic examinations for 2 consecutive hours at $36-38$ weeks' gestation. Behavioural states analysis was carried out by means of a computerized system (Digital PDP 11) that allowed the recording of several fetal variables including heart rate (FHR), gross body movements (FM), eye movements (FEM) and breathing movements (FBM). FHR was classified in four different patterns (FHRP) according to NiJHUIs et al. [10]; fetal movements were automatically synchronized with FHR and grouped for each FHRP. Several quantitative parameters (i. e. incidence, mean duration, lag time, $\%$ time spent moving) were then computed for each movement. There were no statistical differences in the distribution of FHRP (Fig- data, instead, emphasize howe fetal movements significatively differ between IUGR and healthy fetuses when they are related to fetal heart rate.

In our opinion these findings suggest that the analysis of a single parameter (e. g. FHRP, FEM, FM, FBM) is insufficient for the complete assessment of fetal well-being and the integration of more parameters is required. A computerized approach to fetal behaviour simplifies the simultaneous recording of different parameters thus allowing them to be automatically correlated. Moreover there are advantages in automated quantification of fetal movements since this provides additional information concerning fetal behaviour and in the present study allowed differentiation of normal fetuses from those with IUGR. Further studies are required to evaluate the clinical significance of this quantitative approach to fetal behaviour and these are in progress.

ure 1) between healthy and IUGR fetuses. On the other hand quantitative differences (Table I) were found when the movements investigated were related to FHRP. In IUGR fetuses FEM were mainly represented by low frequency movements (IEM) during both low (FHRP A) and high variability (FHRP B) FHRP (Figure 2), whereas healthy fetuses exhibited mostly rapid eye movements (REM) during FHRP B and absent type of FEM during FHRP A. Moreover IUGR fetuses showed (Figure 3) a reduction of state $1 \mathrm{~F}$ (quiet sleep) and an increase of periods of no coincidence between behavioural state variable when compared to the control group fetuses. These findings, therefore suggest the existence of quantitative differences in fetal behaviour in asymmetrical IUGR fetuses when compared to heatlhy fetuses.

Keywords: Computerized analysis, fetal behaviour, intrauterine growth retardation.

\section{Zusammenfassung}

\section{Computeranalyse von Verhaltenszuständen bei ungleich} wachstumsverzögerten Feten

Das Verhalten von 15 intrauterin ungleich wachstumsverzögerten Feten (IUGR) wurde mit dem einer gesunden Kontrollgruppe verglichen. Die Feten wurden in der 36. -38. SSW über 2 Stunden hinweg einer gleichzeitig cardiotokographischen sowie ultrasonographischen Untersuchung unterzogen. Die Verhaltensanalyse wurde mittels eines Computersystems durchgeführt (Digital PDP 11), welches gleichzeitig mehrere fetale Variablen wie Herzfrequenz (FHF), Ganzkörperbewegungen
(FM), Augenbewegungen (FEM) und Atembewegungen (FBM) aufzeichnete. Die FHF wurde nach NisHuIs et al. (10) in 4 Gruppen unterteilt (FHRP); die fetalen Bewegungen wurden automatisch mit der FHF synchronisiert und dem jeweiligen FHRP zugeordnet. AnschlieBend wurden verschiedene quantitative Parameter (z. B. Inzidenz, mittlere Dauer, zeitliche Verzögerung, Bewegungszeit in \%) für jede Bewegung errechnet. Bezüglich der Verteilung von FHRP wurden keine statistisch signifikanten Unterschiede zwischen gesunden und IUGRFeten gefunden (Abb. 1). Andererseits wurden jedoch 
quantitative Unterschiede (Tab. I) in den Bewegungen festgestellt, wenn diese mit den FHRP korreliert wurden. Bei den IUGR-Feten überwogen FEM niedriger Frequenz (IEM) sowohl bei niedriger (FHRP A) als auch bei höherer Variabilität (FHRP B) (Abb. 2), während sich die gesunden Feten überwiegend durch schnelle Augenbewegungen (REM) in FHRP B-Phasen und ohne REM in FHRP A-Phasen auszeichneten.
Darüber hinaus fand sich bei IUGR-Feten (Abb. 3) eine Verkürzung der 1F-Phasen (ruhiger Schlaf) und eine Zunahme der Abschnitte, die keine Übereinstimmung der das Verhalten beschreibenden Variablen im Vergleich zur Kontrollgruppe zeigten. Diese Ergebnisse lassen auf quantitative Unterschiede im Verhalten ungleicher IUGR-Feten im Vergleich zu gesunden Feten schließen.

Schlüsselwörter: Computeranalyse, fetales Verhalten, intrauterine Wachstumsverzögerung.

\begin{abstract}
Résumé
Analyse informatique des états compartementaux chez les fetus avec retard de croissance dysharmonieux

On a comparé le comportement de 15 fotus avec retard de croissance intra-utérin (RCIU) dysharmonieux avec le comportement d'un groupe témoin de fætus bien portants. Les fœtus ont subi simultanément pendant 2 heures consécutives à $36-38$ semaines de gestation un enregistrement cardiotocographique et une échographie. L'analyse des états comportementaux a été réalisée à l'aide d'un système informatisé (Digital PDP 11) qui permet de recevoir plusieurs variables fotales comprenant le rythme cardiaque (RCF), les mouvements corporels globaux (MF), les mouvements oculaires (MO) et les mouvements respiratoires (MR). On a classé le RCF selon quatre modèles différents (RCFM), comme NIJHUIS et coll. [10]; les mouvements fœtaux ont été automatiquement synchronisés avec le RCF et regroupés pour chaque (RCFM). Plusieurs paramètres quantitatifs (c'est-à-dire incidence, durée moyenne, décalage, \% de temps de mouvement) ont été mis dans l'ordinateur pour
\end{abstract}

chaque mouvement. On n'a pas trouvé de différence statistique entre les fœtus bien portants et les fœtus avec RCIU pour le distribution des RCFM (figure 1). Par ailleurs, on a trouvé des différences quantitatives (table I) pour les mouvements explorés en les corrélant avec les RCFM. Chez les fœtus avec RCIU les MO étaient principalement représentés par des mouvements de basse fréquence que ce soit pour les RCFM de faible instabilité (RCFMA) ou de forte instabilité (RCFMB) (figure 2), alors que les fotus bien portants présentaient des mouvements oculaires rapides (REM) lors des RCFMB et pas de MO lors des RCFMA. En outre, les fotus avec RCIU présentent (figure 3) une diminution du sommeil calme et une augmentation des périodes d'absence de coïncidence entre les variations d'états comportementaux en comparaison des fetus du groupe controle. Ces faits suggèrent l'existence de différences quantitatives de comportement chez les fetus avec RCIU dysharmonieux en comparaison avec les fotus bien portants.

Mots-clés: Analyse informatisée, comportement fœtal, utend de croissance intra-utérin.

\section{References}

[1] Arduini D, G Rizzo, C Giolandino, A Vizzone, S Nava, S Dell' Acqua, H Valensise, C Romanini: The fetal behavioural states: an ultrasonic study. Prenat Diagn 5 (1985) 269

[2] Arduini D, G Rizzo, C Giolandino, H Valensise, S Dell' ACQUa, C RomaninI: The development of fetal behavioural states: a longitudinal study. Prenat Diagn 6 (1986) 117

[3] Arduini D, G Rizzo, S Dell' Acqua, S Mancuso, C Romanin: The effect of naloxone on fetal behaviour near term. Am J Obstet Gynecol 156 (1987) 474

[4] Arduini D, G Rizzo, C Romanini, S Mancuso: Fetal blood flow velocity waveforms as predictor of growth retardation. Obstet Gynecol 70 (1987) 7

[5] Beckedam DJ, GHA VisSer, JJ de VRIES, HFR PRECHTL: Motor behaviour in the growth retarded fetus. Early Hum Dev 12 (1985) 155
[6] Campbell S, A Thoms: Ultrasound measurement of the fetal head to abdominal circumference ratio in the assessment of growth retardation. Br J Obstet Gynaecol 84 (1977) 165

[7] DREYFus-Brisac C: Ontogenesis of sleep in human prematures after 32 weeks of conceptional age, Dev Psychobiol 3 (1970) 91

[8] FREDRICK J, P ADELSTEIN: Factors associated to with low birthweight of infants delivered at term. Am J Obstet Gynecol 85 (1978) 1

[9] Gagliardi L, CU Preve, C. Corduro di Montezemolo, GP NATtone, A Piazza: Accrescimento intrauterino ed eta' gestazionale in un campione di 9774 casi. Ann Ostet Ginecol Med Perinat 96 (1975) 147

[10] Nijhuis JG, HFR PrechtL, CB Jr Martin, RSGM BoTs: Are there behavioural states in the human fetus?, Early Hum Dev 6 (1982) 177 
[11] NuHHUI JG: Behavioural states: cocomitants, clinical implications and the assessment of the condition of the nervous system. Eur J Obstet Gynecol Reprod Biol 21 (1986) 301

[12] Peters LLH, RE Sheldon, MD Jones: Blood flow to organs as a function of arterial oxygen content. Am J Obstet Gynecol 135 (1979) 637

[13] PrechtL HFR: The behavioural states of the newborn infant (A review). Brain Res 76 (1974) 185

[14] Rizzo G, D Arduini, F Pennestri', C Romanini, S MANCUSO: Effects of growth retardation on fetal, behaviour: its relationship to fetal blood flow. Prenat Diagn 7 (1987) 229

[15] Rizzo G, D arduini, S Mancuso, C Romanin: Computer-assisted analysis of fetal behaviural states. Prenat. Diagn. 8 (1988) in press
[16] Sabel KG, R Olegard, L Victorin: Remaining sequele with modern perinatal care. Pediatrics 57 (1976) 652

[17] Trudinger BJ, PJ Lewis, B PetitT: Fetal breathing patterns in intrauterine growth retardation. $\mathrm{Br} \mathrm{J}$ Obstet Gynaecol 86 (1979) 432

[18] van Vliet MA, CB JR Martin, JG Nijhuis, HFR PRECHTL: Behavioural states in growth retarded human fetuses. Early Hum Dev 12 (1985) 183

Domenico Arduini, M. D.

Ist. Cl. Ostetrica e Ginecologica Universita' Cattolica S. Cuore Largo A. Gemelli, 8 00168 Rome

Italy 


\section{Recent Advonces in Steroid Hormone Action}

\section{Editor V. K. Moudgil}

$1987.17 \mathrm{~cm} \times 24 \mathrm{~cm}$. VIII, 552 pages. Numerous illustrations. Hardcover. DM 270,-; approx. US \$ 159.00 ISBN 3110107627

Steroid hormones are involved in numerous complex physiological and developmental processes. During the past three years, there has been an explosion of new information on the structure and function of steroid receptors and their genes.

This book contains invited chapters contributed by leading scientists in the general area of molecular mechanism of steroid hormone action. The authors have applied new technology to closely examine facets of molecular organization of steroid regulation. The chapters in the book have been prepared to provide a reader with sufficient background, needed methodological details and discussion that is easy to comprehend.

Contents (Main Chapters)

Introduction - Cloning of Steroid Receptors and Gene Expression · Steroid Hormone Receptors: Structure and Modifications - Analysis of Steroid Receptors in Cancer Cells - Advances in Methodological Approaches · Author Index · Subject Index.

Price is subject to change without notice

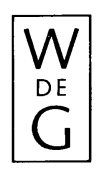

de Gruyter · Berlin · New York 